\title{
NUMERICAL MODEL OF AVIATION GEARBOX TEST RIG IN A CLOSED LOOP CONFIGURATION
}

\author{
Tadeusz Markowski ${ }^{1}$, Stanislaw Noga ${ }^{1}$, Stanislaw Rudy ${ }^{2}$ \\ ${ }^{1}$ Rzeszów University of Technology, Department of Machine Design, ul. W. Pola 2, 35-959 Rzeszów, Poland \\ ${ }^{2}$ WSK PZL Rzeszów S.A., Department of Strength Analysis, ul. Hetmańska 120, 35-078 Rzeszów, Poland \\ E-mail:tmarkow@prz.edu.pl; noga@prz.edu.pl,Stanislaw.Rudy@wskrz.com
}

Received 30 November 2009, accepted 22 February 2010

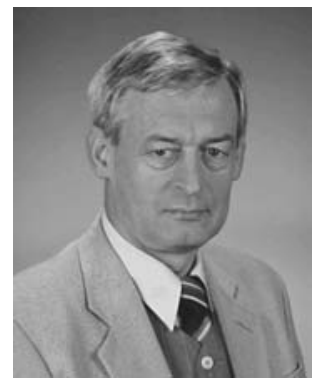

Tadeusz MARKOWSKI, Prof Dr Eng

Education: Rzeszów University of Technology, Faculty of Mechanical Engineering, MSc Eng. degree, 1970; Poznań Technical University, Faculty of Mechanical Engineering, PhD, 1978; Poznań Technical University, Faculty of Mechanical Engineering, DSc degree in mechanics, 1992; Full professor, 1999.

Research interests: mechanics, construction and exploitation of machines, gear transmissions.

Publications: more than 50 scientific papers, 10 conference works, 4 books, 6 patents.

Awards: laureate of science prizes.

Present position: head of Department of Machine Design, Faculty of Mechanical Engineering and Aeronautics, Rzeszow University of Technology.

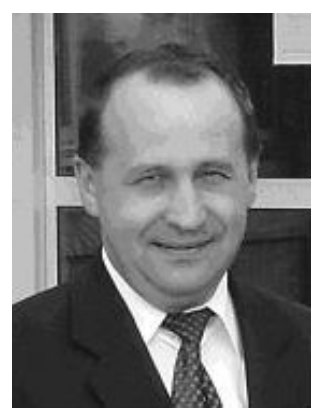

Stanisław NOGA, PhD Eng

Education: Rzeszów University of Technology, Faculty of Mechanical Engineering and Aeronautics.

Affiliations and functions: 1995-2004 - research assistant; 2004-present - assistant professor at Rzeszów University of Technology.

Research interests: dynamics of mechanical systems.

Publications: 20 scientific articles and conference papers.

Present position: Assistant Professor, Rzeszow University of Technology, Department of Machine Design.

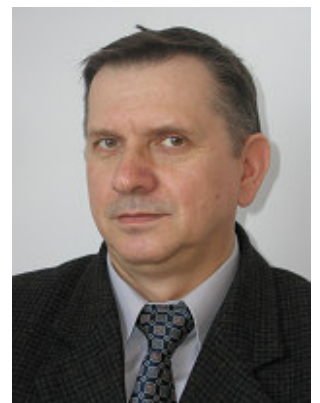

\section{Stanisław RUDY, MSc Eng}

Education: Academy of Mining and Metallurgy, Cracow, MSc Eng degree, 1974.

Affiliations and functions: 1974-present, WSK PZL - Rzeszów S.A.

Research interests: stress and dynamic analysis.

Publications: 9 scientific articles and conference papers.

Present position: manager of Analytical Department, WSK PZL - Rzeszów S.A.

\begin{abstract}
The development of computer techniques and computational systems based on the finite element method allows one to conduct a free vibration analysis of large systems like an aviation gearbox test rig. The object of this paper is to present a free vibration analysis of a gear fatigue test rig working in a closed loop configuration. A numerical model of the test rig based on the finite element method is presented in this paper. The base model contains all the essential structures of the real system. After the numerical results of the natural frequencies of the rig were obtained, they were then verified by the experimental results on a real object. Numerical analysis was performed using the ANSYS code.
\end{abstract}

Keywords: aviation gearbox test rig, natural frequencies, mode shapes, modal analysis. 


\section{Introduction}

The growth of modern engineering requires technical equipment to be characterized by high durability and operational reliability. This particularly applies to components and assemblies used in the aviation industry. Each newly produced assembly must pass a set of experimental tests, which allow it to be used in aviation construction. For economic reasons, these experimental tests should be conducted on specially designed test rigs. Such test rigs are required to fulfil specific requirements to guarantee that experiments can be conducted with high technical quality, and economic reasons demand that the rigs should operate for a long period of time (Goliński 1979). One of the essential factors, which could disturb or limit the operation of a rig, is the vibration of the components or assemblies of the rig. Because of this reason, it is beneficial to conduct numerical modelling tests at the design stage, which could limit the consequences of the rig vibration (De Silva 2005).

The rapid growth of computer techniques and analytical systems based on the finite element method (FEM) allows a free vibration analysis of large systems of complex design and geometry to be conducted (Bathe 1996; Friswell et al. 1995). Some authors, using FEM techniques, analyzed free vibrations of complex structures, which are used as load-bearing elements of building structures (Ansell 2005; Begum et al. 2007; Brownjohn et al. 2001; Buonopane et al. 2006; Moon et al. 2000). According to A. R. Kukreti (Kukreti et al. 2006) the modelling of dynamic behaviour of steel frame joints was investigated. According to J. J. Wu (2004) the vibration of a gantry crane was analysed. The FE crane model that was developed was verified on a real object. Free vibration analysis of selected steel bridges was conducted in papers of W. Chung, Y. Sieffert, S. Živanovič (Chung et al. 2006; Sieffert et al. 2006; Živanovič et al. 2007). Just as in the previous case, the models that were developped were verified by experiments. Z. Zembaty (Zembaty et al. 2006) investigated the influence of damage of the base construction frame on the change in the natural frequencies of the system.

The subject of this paper is to analyze the free vibrations of a gear fatigue test rig working in a closed loop configuration. T. Markowski (Markowski et al. 2009) presents introductory studies that deal with the vibrations of the system being studied. The test rig consists of a base frame on which an additional steel frame, together with other assemblies, is mounted. Based on the technical documentation of the analyzed system, a FE model was prepared using the ANSYS code. This paper presents the numerical results of the free vibrations of the analyzed structure. The numerical results that were obtained were then verified by the experimental investigation on a real object. This paper is a continuation of the works concerning the dynamics of mechanical systems using the FEM approach (Noga 2007; Noga 2008).

\section{Description of the gear fatigue test rig working in closed loop configuration}

The test rig in question was created at the Test Bed Shop of the Wytwórnia Sprzętu Komunikacyjnego PZL Rzeszów S.A. A block diagram is presented in figure 1 .

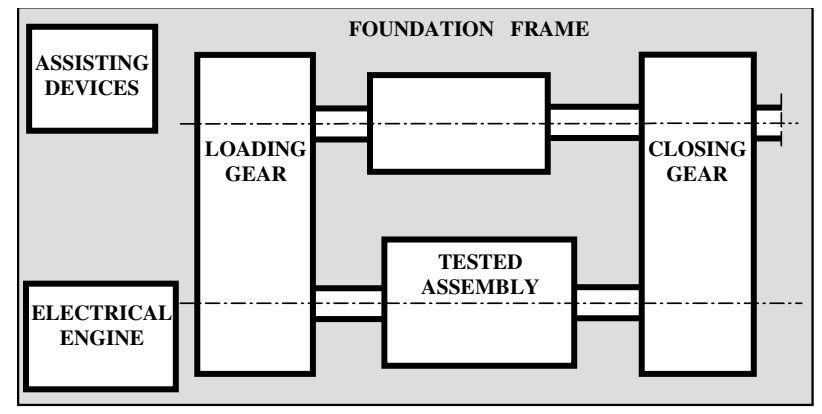

Fig 1. Test rig block diagram

All assemblies of the rig are mounted on the additional frames seated on the base frame, the design of which is shown in figure 2. The frame consists of two layers of structural section with channel section shapes 180 and 50 welded together (Bogucki et al. 2005) and fastened to the concrete base by anchors (Kisiel 1957). The upper layer contains the six sets of channel sections consisting of two-channel sections 180 , each $4100 \mathrm{~mm}$ in length. The lower layer consists of seven segments, out of which the two external ones and the central one contain sets of channel sections 180, each $2000 \mathrm{~mm}$ in length. The remaining segments in the collaboration area with the four internal sets of the upper layer are built from one channel section. The upper layer sets are additionally reinforced by channel section 50 (Fig 2).

The frame is fastened to the base by fourteen anchors along the longer side (seven anchors per side). To the upper layer bolts fasten additional frames with additional rig assemblies. The estimated weight of the base frame is $1600 \mathrm{~kg}$.

Each additional steel frame consisting of structural square section $100 \times 100 \times 6$ or rectangular section $100 \times 50 \times 6$ and $100 \times 50 \times 8$ has at the upper end a plate made of steel sheet $20 \mathrm{~mm}$ thick (Bogucki et al. 2005). All additional frames of the rig are welded. On the individual plates of the additional frames, the applicable assemblies of the rig are mounted together with additional features, which are used for the stability and accuracy of the assembly process of the rig (Goliński 1979). 


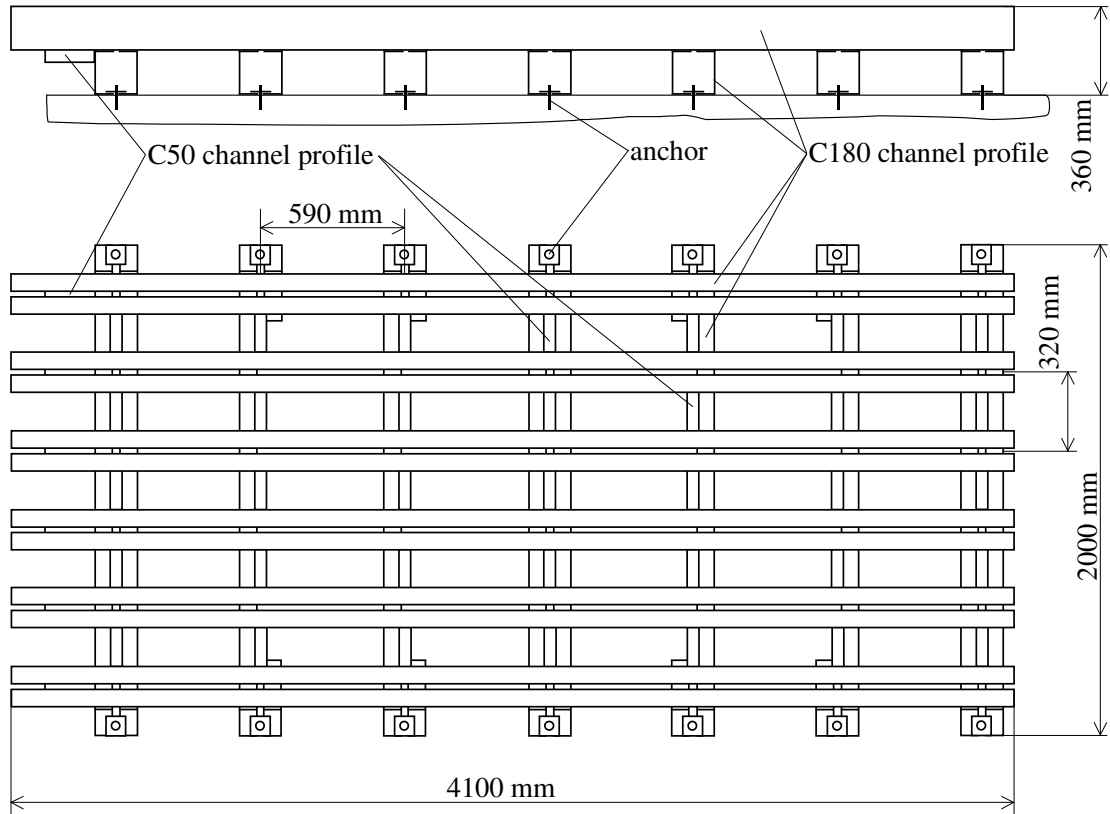

Fig 2. Geometrical model of test rig frame

In figure 3 , the rig in question is presented. The total estimated weight of the whole rig is $6500 \mathrm{~kg}$. The rotating assemblies of the rig are working in the rotating range of 2700-7500 rpm, which, if converted into number of cycles, equals $45-125 \mathrm{~Hz}$ without taking into consideration the multiplication factor of the number of teeth. At the assembly of the test rig, it was found that the assembled rig vibrates under the influence of ground excitation, which is caused by working neighboring test rigs. There was a real danger that those vibrations would disturb the operation of the rig. The necessity of dynamic rig analysis in order to estimate natural frequencies and mode shapes was recognized.

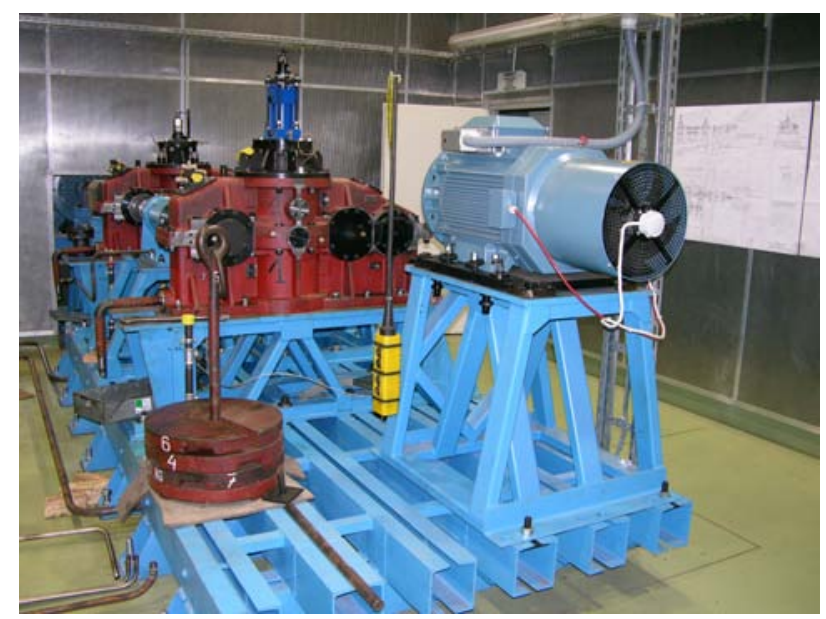

Fig 3. Gear fatigue test rig - overall view

\section{Numerical model of the rig}

To obtain satisfactory modal analysis results, an accurate FE model of the system must be worked out before conducting an experimental investigation on a real object. Such a primary dynamic overview of the system is helpful in planning and conducting the experimental investigation (De Silva 2005).

The test rig is a complex system composed of various structural components. The primary aim is to develop a model of the rig that has dynamic parameters (frequency and mode vibration) as close as possible to the parameters of the real object. From an economic point of view, the prepared model should be so simple that the costs connected with development and operation should amount to a bare minimum (De Silva 2005). In this respect, the key factor is the selection of the proper elements for modelling particular structural components and assemblies of the rig. The numerical model of the test rig was worked out by the ANSYS FE code (ANSYS ...2005).

From the point of view of the stability of the test rig, the base frame is the essential structural component (Fig 2). Because of this, the detailed FEM model of the frame was elaborated using shell elements (shell99) quadrilateral, eight nodes with six degrees of freedom on each node. Sets of channel sections of the base frame were modelled with shell99, assuming the location of the nodes on the external surface of the element (Fig 4). This allowed simple realization of the welded joints by merging nodes in the welded areas (Fig 4). This approach introduces modelling error because of the excessive mass concentration in the corner of the channel sections, which results in improper inertia moments of the sets of channel sections.

The frame support was modelled assuming constraint pointwise in the areas where the frame is attached to the base by the anchors.

In each point, one rotational degree of freedom along the axes of the anchor has been left free (Fig 5). Additional reinforcement of the external sets of channel sections in the upper layer was modelled by the beam element beam 44. 

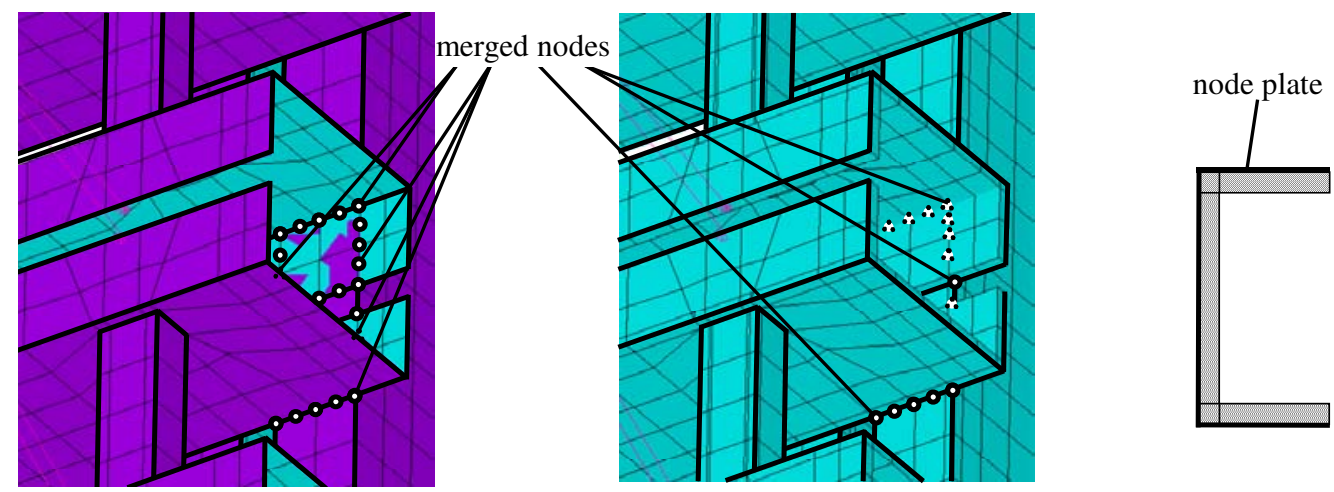

Fig 4. Realization of welded joints by the application of the "merge nodes" option

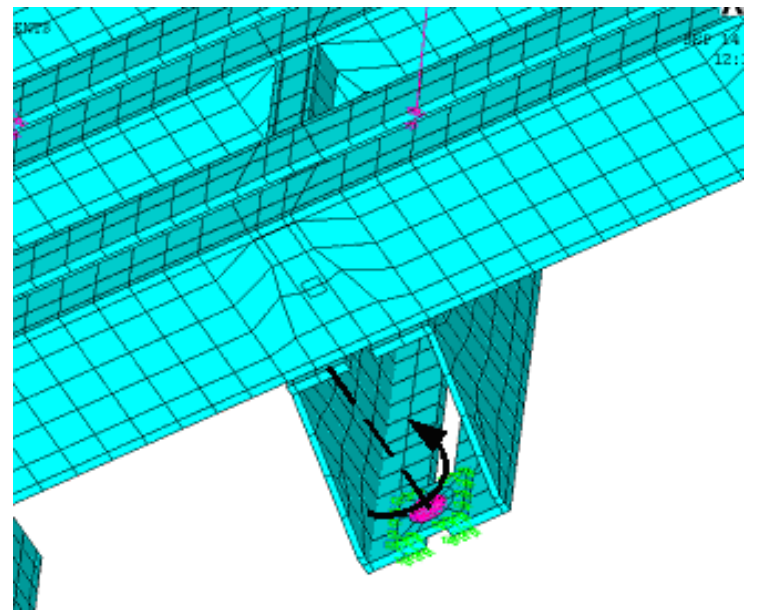

Fig 5. Boundary conditions

Each of the rig assemblies together with corresponding additional frames (with the exception of supporting device (figure 1) was modelled as a rigid region concen- trated at the mass point where total mass is located. In the rigid region, two types of nodes can be distinguished: master nodes and slave nodes subordinated to the master node (ANSYS...2005). This means that slave nodes have the same DOF as master nodes with reference to the discussed rig, in all the applied rigid regions the location of the master nodes overlaps with the location of mass points located in the centre of gravity of the modelled assemblies. Each mass point is realized by a single node mass element, mass 21 , with six DOF. The nodes of the frame located in the collaboration areas of the modelled assemblies and modelled frame were considered the slave nodes of the particular rigid regions. The completed finite element model of the rig is presented in figure 6. The model consists of 18208 shell elements (shell99), 19 mass point elements (mass 21), 14 beam elements (beam44), and 56892 nodes. As was mentioned earlier, a model of the supporting device was not taken into consideration in this model.

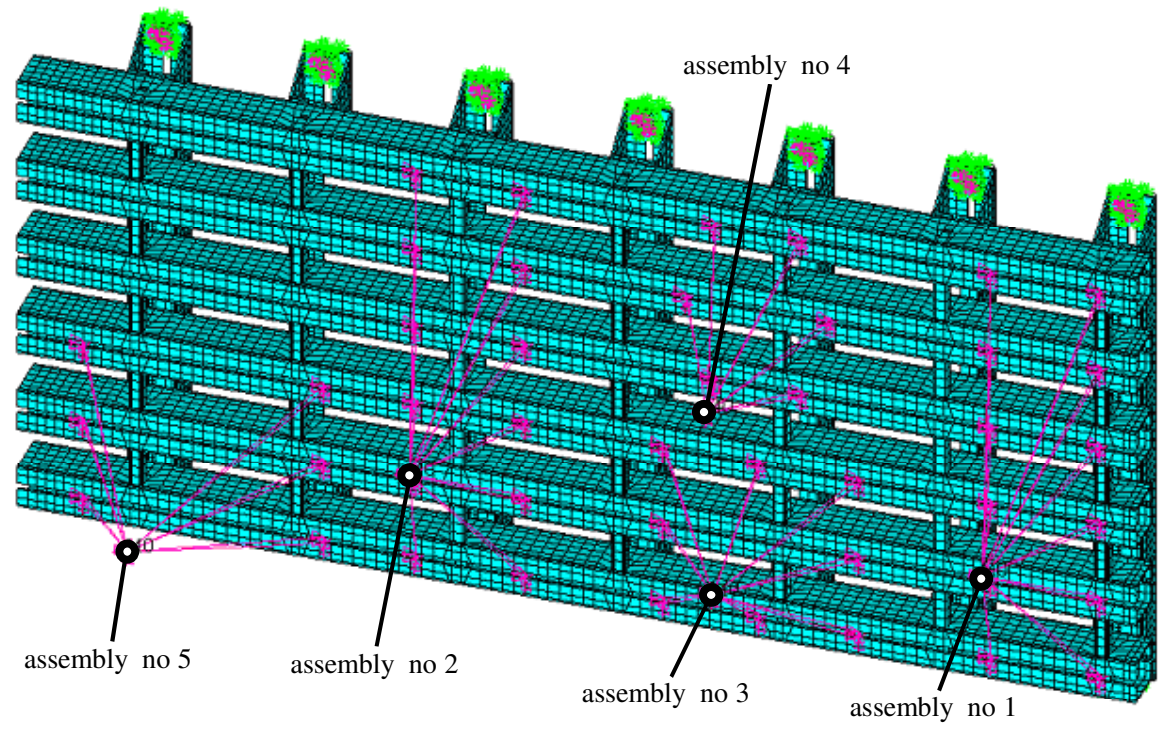

Fig 6. Numerical model of the test rig (FEM)

On the basis of the model developed, numerical calculations were conducted to evaluate the natural frequencies of the system and corresponding mode shapes in the frequency range 0 to $300 \mathrm{~Hz}$. For the steel elements used for the rig, the following data materials were used: Poisson ratio $v=0.3$, Young's modulus $E=2.1 * 10^{11} \mathrm{~Pa}$, 
and density $\rho=7.86 * 10^{3} \mathrm{~kg} / \mathrm{m}^{3}$. The evaluated mass of the particular assemblies of the test rig (Fig 6) is presented in table 1 .

Table 1. Evaluated mass of the particular assemblies of the rig

\begin{tabular}{|c|c|c|c|c|c|}
\hline Assembly no. & 1 & 2 & 3 & 4 & 5 \\
\hline Mass [kg] & 1480 & 1480 & 550 & 320 & 600 \\
\hline
\end{tabular}

The results were split into two categories. Natural frequencies and mode shapes related to the movement of assemblies mounted on the base frame were considered a first category. The other category includes natural frequencies and mode shapes related to the local movement of the sets of channel sections of the base frame. The vibrations of assemblies with mode shapes close to the first category have bigger consequences for proper rig operation because of the movements of the particular assemblies when the rig is running. The vibration of the particular assemblies can be realized as a concurrent oscillation form when the sense of movement has the same signs or a backward oscillation form when sense of movement has the opposite signs.

The numerical analysis results are presented below with reference to the mode shapes and natural frequencies related to the movements of the particular rig assemblies. The results are presented in table 2 in order of occurrence. In order to unambiguously describe the mode shapes presented, it is assumed that longitudinal movement is a movement in the plane parallel to the base and along the longer side of the base frame (Fig 2). Transverse movement is a movement in the plane parallel to the base and along the shorter side of the base frame. Vertical movement is considered perpendicular to base movement. Natural frequency values and descriptions of the corresponding mode shapes are presented in table 2. The graphic form of the rig mode shapes is presented in the appendix to this paper. The values of the natural frequencies of the rig corresponding to modes 3-10 are within the operating range of the rotating parts of the rig assemblies.

Table 2. Natural frequency and mode shapes of the test rig

\begin{tabular}{|c|l|c|c|}
\hline Mode no. & \multicolumn{1}{|c|}{ Mode shape description } & $\begin{array}{c}\text { Value of the natural } \\
\text { frequency } \omega^{m}[\mathrm{~Hz}]\end{array}$ & Figure no. \\
\hline 1 & Concurrent longitudinal vibrations of all assemblies & 22.068 & 9 \\
\hline 2 & Vertical vibrations of assembly no. 1 & 37.764 & 10 \\
\hline 3 & Backward vertical vibrations of assemblies no. 1 and 2 & 40.661 & 11 \\
\hline 4 & Concurrent transverse vibrations of all assemblies & 51.745 & 12 \\
\hline 5 & Vertical vibrations of assembly no. 5 & 57.672 & 13 \\
\hline 6 & Backward transverse vibrations of assemblies no. 1 and 2 & 59.273 & 14 \\
\hline 7 & Vertical vibrations of assembly no. 3 & 73.346 & 15 \\
\hline 8 & Vertical vibrations of assembly no. 4 & 85.160 & 16 \\
\hline 9 & $\begin{array}{l}\text { Concurrent transverse vibrations of assemblies no. 3 and 4 and } \\
\text { backward with assembly no. 5 }\end{array}$ & 93.031 & 17 \\
\hline 10 & Concurrent vertical vibrations of assemblies no. 3, 4 and 5 & 101.70 & 18 \\
\hline 13 & $\begin{array}{l}\text { Concurrent vertical and transverse vibrations of assemblies no. 3 } \\
\text { and 4. }\end{array}$ & 138.71 & 19 \\
\hline
\end{tabular}

\section{Experimental investigations}

The prepared FE model of the rig was verified by experimental investigation on a real object (Fig 3). A Brüel and Kjær measuring set was used in the experimental investigation. The set consisted of a modal hammer, 8202 equipped with gauging point made of composite material, 4384 accelerometer, analogue signal conditioning system, acquisition system, and data processing system supported by LabView analytical software. Analysis of the results of the experimental investigation was conducted on a portable computer using actual measured values.

The measurement experiment was scheduled and conducted to identify natural frequencies and correspondding mode shapes related to the transverse, longitudinal and vertical form vibration of assemblies no. 1 and 2 .

Because only one accelerometer was accessible, the measurement process was conducted in a so-called measurement group. For each group, the accelerometer position for a tap place point for the hammer (impulse excitation) was established. In figure 7 , one of the measurement groups is shown, where the accelerometer is placed at point $\mathrm{A}$ and in the other points the modal hammer forced vibrations. The complete description of the experimental investigations conducted on the test rig will be the subject of another paper.

The quality of the FE test rig model was defined as a relative error defined by formula (Friswell et al. 1995):

$$
\varepsilon=\left(\omega^{m}-\omega^{e}\right) / \omega^{e} \times 100[\%],
$$

where $\omega^{m}$ is the natural frequency from numerical analysis, while $\omega^{e}$ is the frequency determined during experimental investigation. Table 3 defines the natural frequencies excited and identified in the measurement experiment, their corresponding mode shapes, and relative error defined according to formula (1). 


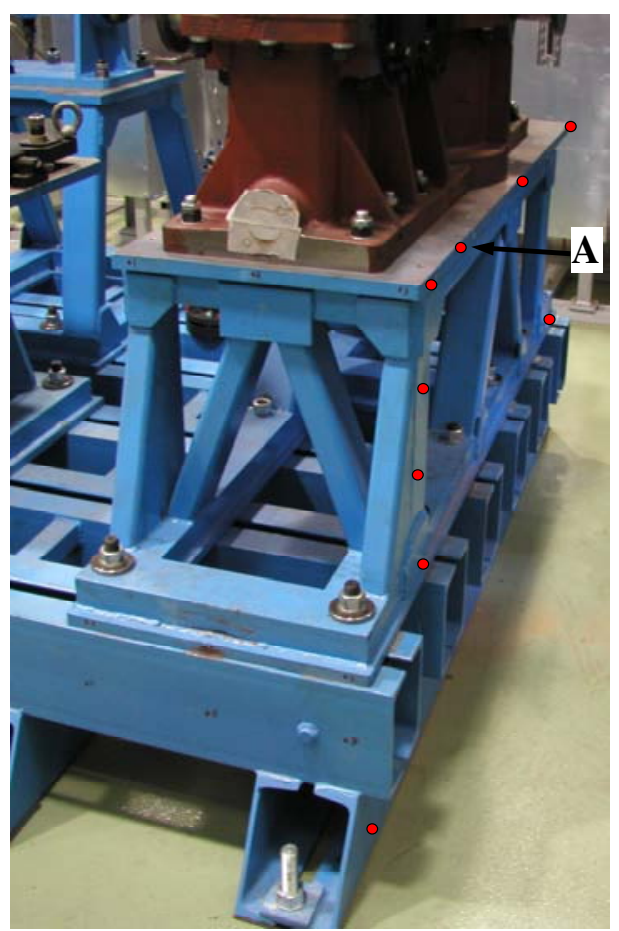

Fig 7. Frequency characteristic of the system

a)

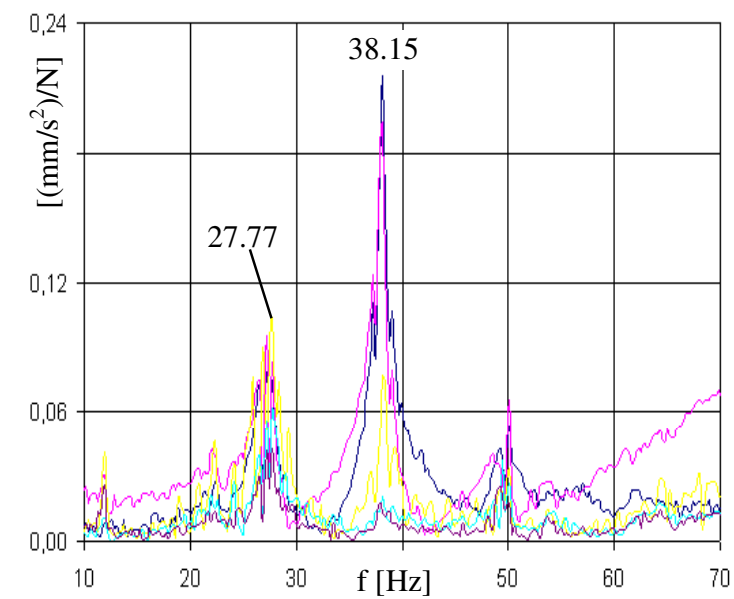

Form identification was conducted by qualitative comparison of the numerical and experimental results. In figure 8 , the frequency characteristic of the system for a selected measured group (figure 8) is presented. Figure $8 \mathrm{a}$ presents the amplitude-phase characteristic, while figure $8 \mathrm{~b}$ presents the phase-frequency characteristic.

Considering the data from table 3 , one can observe small differences between numerical and experimental results with reference to the natural frequencies of the vertical vibration forms of the rig (mode shapes no. 2, 5, and 7). A considerable difference appeared for natural frequencies concerning the rig vibration in the base frame plane direction.

Table 3. Experimental investigation results

\begin{tabular}{|c|c|c|}
\hline $\begin{array}{c}\text { Mode } \\
\text { no. }\end{array}$ & $\begin{array}{c}\text { Measured natural frequency } \\
\text { value } \omega^{e}[\mathrm{~Hz}]\end{array}$ & $\begin{array}{c}\text { Frequency relative } \\
\text { error } \varepsilon[\%]\end{array}$ \\
\hline 1 & 27.77 & -20.5 \\
\hline 2 & 38.15 & -1.01 \\
\hline 4 & 46.70 & 10.8 \\
\hline 5 & 56.15 & 2.71 \\
\hline 7 & 73.24 & 0.15 \\
\hline
\end{tabular}

b)

$\begin{array}{llllll}10 & 20 & 30 & \mathrm{f}[\mathrm{Hz}] & 50 & 60\end{array}$

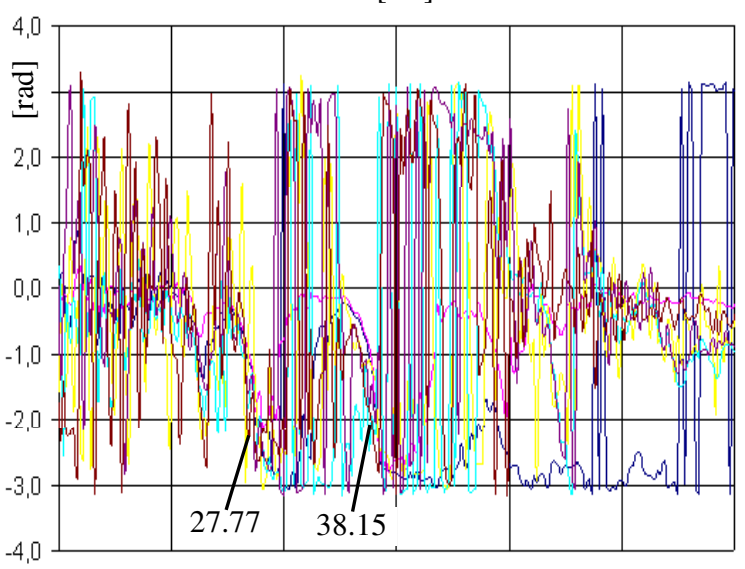

Fig 8. Measuring set example

\section{Conclusions}

The design and creation of modern aviation test rigs require the use of advanced numerical software based on the finite element method. This allows the specific design features and complex geometry of the rig to be taken into consideration. In the scientific literature cited in this paper, modern vibration analysis methods were used for complex systems like bridges, construction frames, and gantry cranes. In this paper, a gear fatigue test rig working in a closed loop configuration was analyzed. Some portion of the natural frequencies and modes received from numerical calculations were verified in the experimental investigations. Considering the results, one can find remarkable consistency between the numerical and experimental results with reference to the natural frequencies of the vertical vibration forms of the rig.
Lower consistency appeared for the natural frequencies concerning the rig vibration in the base frame plane direction. Further investigation will be oriented towards developing a more advanced numerical model allowing better consistency between numerical and experimental results to be obtained. The advanced model would take into consideration the geometry of the additional frames used for supporting particular assemblies of the rig presented. The advanced model would also allow determining additional natural frequencies and mode shapes not found on the basis of the analysis of the current FE model of the rig. These results would be helpful to establish the consistency between natural frequencies and mode shapes received from numerical calculations and unidentified natural frequencies and mode shapes in the experimental investigations. 


\section{Acknowledgement}

MSc Eng Mieczysław Kozłowski and MSc Eng Wojciech Obrock, I - WSK PZL Rzeszów S.A. employees - took part in the experimental investigations.

\section{Appendix}

Graphical visualization of the mode shapes of the rig from table 2 .

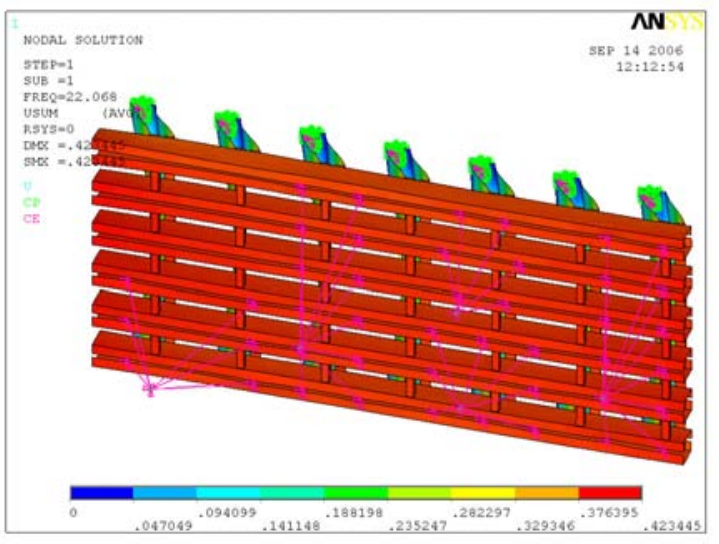

Fig 9. Mode shape no. 1

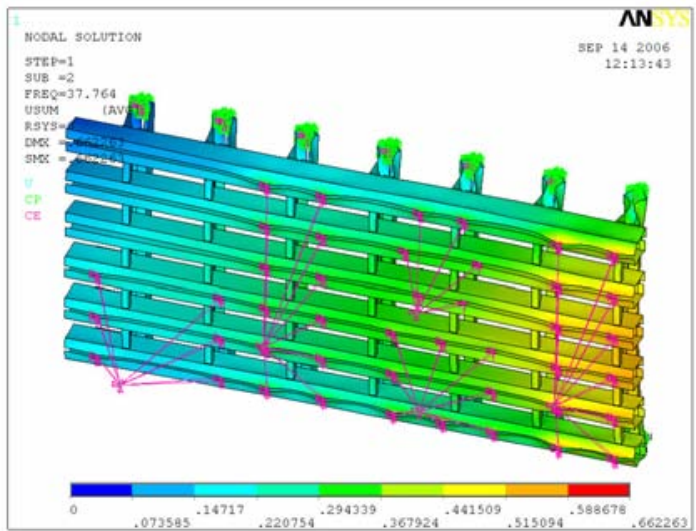

Fig 10. Mode shape no. 2

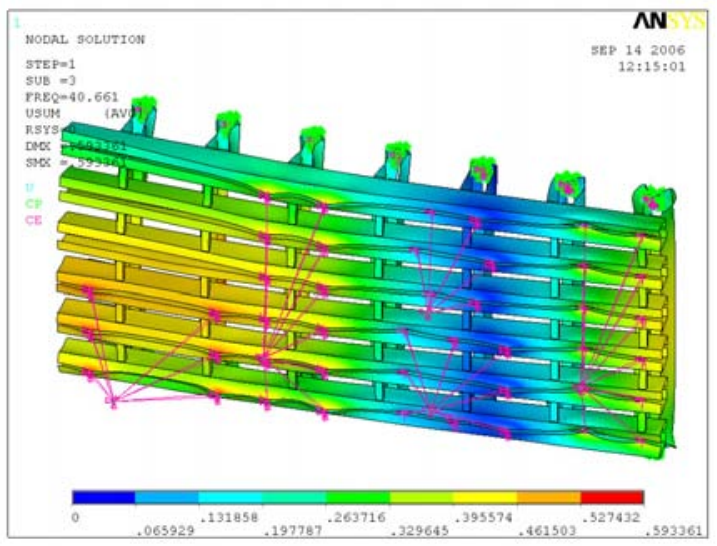

Fig 11. Mode shape no. 3

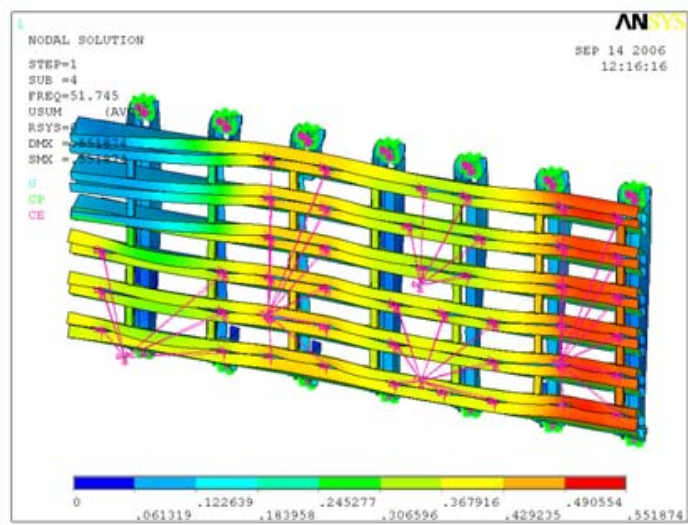

Fig 12. Mode shape no. 4

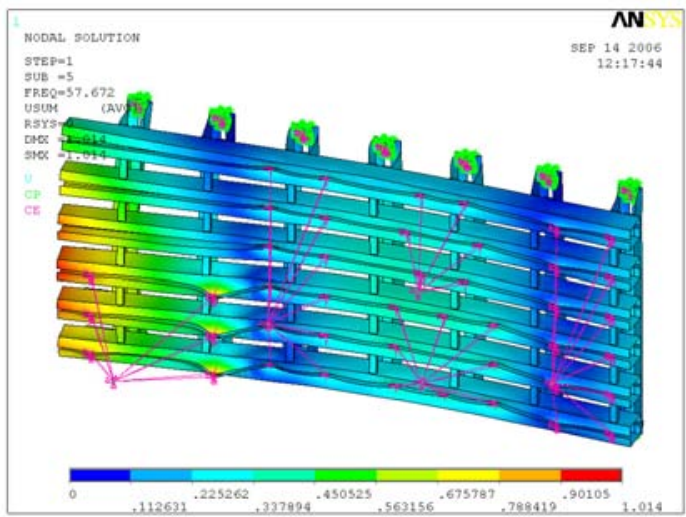

Fig 13. Mode shape no. 5

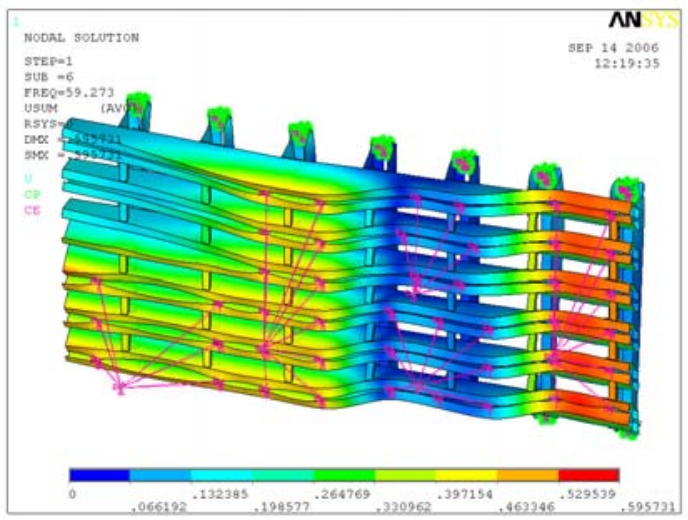

Fig 14. Mode shape no. 6

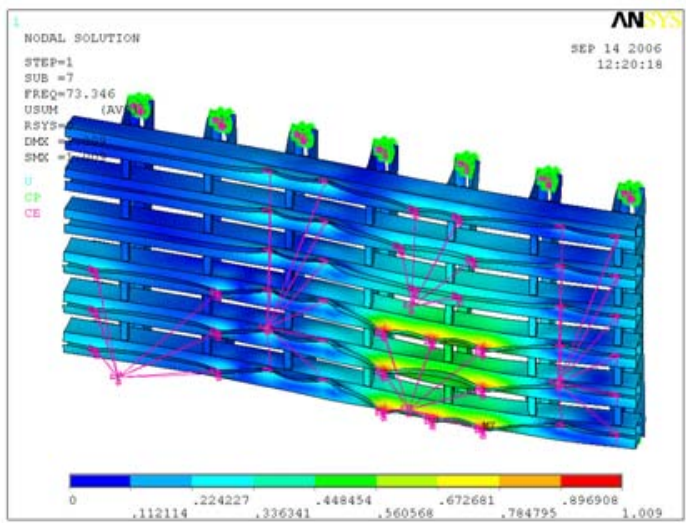

Fig 15. Mode shape no. 7 


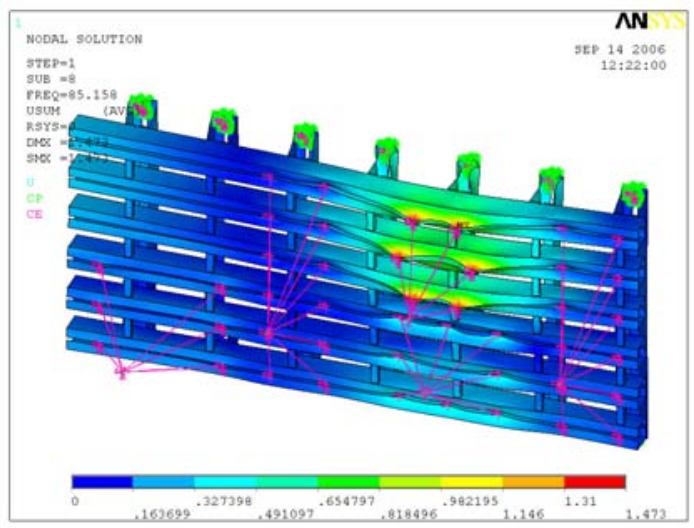

Fig 16. Mode shape no. 8

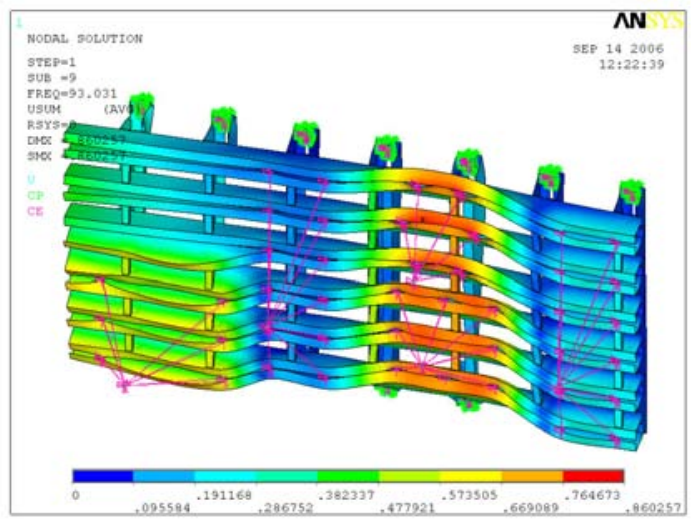

Fig 17. Mode shape no. 9

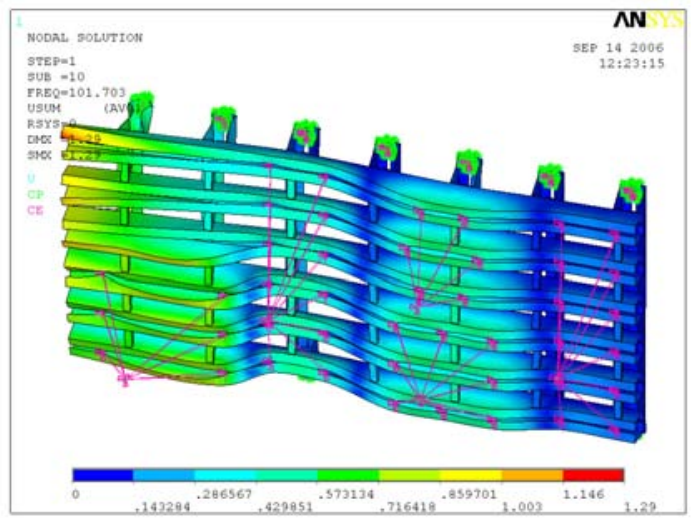

Fig 18. Mode shape no. 10

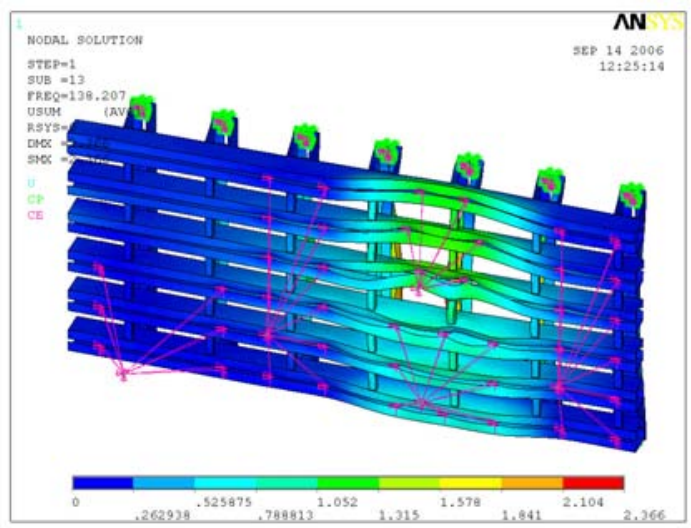

Fig 19. Mode shape no. 13

\section{References}

Ansell, A., 2005. The dynamic element method for analysis of frame and cable type structures, Engineering Structures 27: 1906-1915.

Bathe, K. J. 1996. Finite Element Procedures. Englewood Cliffs (NJ): Prentice Hall.

Begum, M.; Driver, R. G.; Elwi, A. E. 2007. Finite element modeling of partially encased composite columns using the dynamic explicit method, Journal of Structural Engineering 133: 326-334.

Bogucki, W.; Żyburtowicz, M. 2005. Tables to Design Metallic Structures. Warsaw: Arkady (in Polish).

Brownjohn, J. M. W.; Xia, P. Q.; Hao, H. et al. 2001. Civil structure condition assessment by FE model updating: methodology and case studies, Finite Elements in Analysis and Design 37: 761-775.

Buonopane, S. G.; Schafer, B. W. 2006. Reliability of steel frames designed with advanced analysis, Journal of Structural Engineering 132: 267-276.

Chung, W.; Sotelino, E. D. 2006. Three dimensional finite element modeling of composite girder bridges, Engineering Structures 28: 63-71.

De Silva, C.W. 2005. Vibration and Shock Handbook. Boca Raton: Taylor \& Francis.

Friswell, M. I.; Mottershead, J. E. 1995. Finite Element Model Updating in Structural Dynamics. Dordrecht: Kluwer Academic Publishers.

Goliński, J. 1979. Vibration Isolation of Machines and Devices. Warsaw: WNT (in Polish).

Kisiel, I. 1957. Dynamics of Machine Foundations. Warsaw: PWN (in Polish).

Kukreti, A.R.; Zhou, F.F. 2006. Eight-bolt endplate connection and its influence on frame behaviour, Engineering Structures 28: 1483-1493.

Markowski, T.; Noga, S., Rudy, S. 2009. Numerical model of a stand for the examination of the aviation gear trains in a circulating power system, in The $13^{\text {th }}$ International School "Computer Aided Design, Manufacturing and Operation", Jurata, Poland, 219230 (in Polish).

Moon, D. H.; Choi, M. S. 2000. Vibration analysis for frame structures using transfer of dynamic stiffness coefficient, Journal of Sound and Vibration 234: $725-736$.

Noga, S. 2007. Dynamical analysis of the low-power electrical engine rotor, in The $10^{\text {th }}$ European Mechanics of Materials Conference "Multi-phases and multi-components materials under dynamic loading”, Kazimierz, Poland, 457-465.

Noga, S. 2008. Numerical analysis of a free transverse vibration of an elastically connected annular doublemembrane compound system, Acta Mechanica Slovaca 3-A: 307-312.

Sieffert, Y.; Michel, G.; Ramondenc, P. et al. 2006. Effects of the diaphragm at midspan on static and dynamic behaviour of composite railway bridge: A case study, Engineering structures 28: 1543-1554.

Wu, J. J. 2004. Finite element modelling and experimental modal testing of a three dimensional framework, International Journal of Mechanical Sciences 46: $1245-1266$. 
Zembaty, Z.; Kowalski, M.; Pospisil, S. 2006. Dynamic identification of a reinforced concrete frame in progressive states of damage, Engineering Structures 28: 668-681.

Živanović, S.; Pavic, A.; Reynolds, P. 2007. Finite element modelling and updating of a lively footbridge: the complete process, Journal of Sound and Vibration 301: 126-145.

ANSYS documentation. 2005.Version 10.0. ANSYS, Inc.

\section{AVIACINĖS PAVARŲ DĖŽĖS TESTAVIMO İRENGINIO SKAITINIO MODELIO PANADOJIMAS UŽDARO KONTŪRO KONFIGŪ- RACIJOJE}

\section{T. Markowski, S. Noga, S. Rudy}

S antrauka

Baigtiniu elementu metodu paremtas kompiuterinès technikos ir kompiuterinių sistemų kūrimas leidžia atlikti laisvujų svyravimu analizę tokios didelès sistemos, kaip aviacinès pavarų děžès, testavimo įrenginys. Šio darbo tikslas buvo atlikti pavarų děžès nuovargio bandymu irenginio, veikiančio uždaro kontūro konfigūracijoje, laisvujų svyravimų analizę. Taip pat pateikiamas testavimo ịrenginio skaitinis modelis, kurio veikimas yra pagrisstas baigtinių elementų metodu. Pagrindinis modelis turi visas tikrosios sistemos svarbiausias struktūras. Gavus i̇renginio savujų dažniu kiekybinius rezultatus, buvo patikrinti realaus objekto eksperimentiniai rezultatai. Naudojantis ANSYS sistema buvo atlikta skaitiné analizė.

Reikšminiai žodžiai: aviacinès pavarų dèžès testavimo ịrenginys, savieji dažniai, modų formos, modalinè analizė. 